\title{
Sibling Species of Cercospora Associated with Gray Leaf Spot of Maize
}

\author{
Juan Wang, Morris Levy, and Larry D. Dunkle
}

First and third authors: Crop Production and Pest Control Research, U.S. Department of Agriculture-Agricultural Research Service, Department of Botany and Plant Pathology, Purdue University, West Lafayette, IN 47907-1155; and second author: Department of Biology, Purdue University, West Lafayette, IN 47907-1392.

Accepted for publication 14 August 1998.

\begin{abstract}
Wang, J., Levy, M., and Dunkle, L. D. 1998. Sibling species of Cercospora associated with gray leaf spot of maize. Phytopathology 88:1269-1275.

Monoconidial isolates of the fungus causing gray leaf spot of maize were obtained from diseased leaves collected throughout the United States and analyzed for genetic variability at 111 amplified fragment length polymorphism (AFLP) loci. Cluster analysis revealed two very distinct groups of Cercospora zeae-maydis isolates. Both groups were found to be relatively uniform internally with an average genetic similarity among isolates of approximately 93 and $94 \%$, respectively. The groups were separated from each other by a genetic distance of approximately $80 \%$, a distance greater than that separating each group from the sorghum pathogen, $C$. sorghi $(67$ to $70 \%)$. Characteristics and dimensions of conidia and conidiophores produced on infected plants or nutrient media were unreliable criteria for taxonomic differentiation of isolates composing the two groups of C. zeae-maydis. Nucleotide sequences of 5.8S ribosomal DNA (rDNA)
\end{abstract}

ABSTRACT and the internal transcribed spacer (ITS) regions were identical within each group but different between the two groups and different from $C$. sorghi. Restriction fragment length polymorphisms generated by digestion of the 5.8S rDNA and ITS regions with TaqI readily distinguished each group and $C$. sorghi. Isolates in one group were generally distributed throughout maize-producing regions of the United States; isolates in the other group were localized in the eastern third of the country. Both types were present in the same fields at some locations. The genetic distance based on AFLP profiles and different ITS nucleotide sequences between the two morphologically indistinguishable groups indicate that they are sibling species. Although it is unlikely that breeding for resistance to gray leaf spot will be confounded by local or regional variation in the pathogen, a vigilant approach is warranted, because two pathogenic species exist with unknown abilities to evolve new pathotypes.

Additional keywords: genetic variation, population genetics.
Gray leaf spot has increased in frequency, distribution, and severity during the past 2 decades and has become the major foliar disease of maize, causing substantial economic losses under conditions favorable for disease development. The disease was first reported in 1925 in Illinois by Tehon and Daniels (43), who described and named the causal agent Cercospora zeae-maydis. Because of the low incidence, the negligible effect on yield, and the absence of symptoms until late in the growing season, the disease was considered a minor problem for at least the next 50 years. During the late 1970s and early 1980s, gray leaf spot increased in prevalence and severity in the southeastern and mid-Atlantic states (23). During the past decade, gray leaf spot has become a serious threat throughout the maize-growing regions of the United States and appears to be increasing each year. The increased incidence and severity of gray leaf spot are associated with conservation tillage practices and monoculture of maize, which result in a buildup and survival of inoculum in debris for early infection of the subsequent crop $(10,23,33,34,38)$. The severity of gray leaf spot is frequently greater in the absence of other foliar diseases, because more tissue remains available for colonization throughout the growing season (37). Hence, the development of maize hybrids with resistance to Setosphaeria turcica (northern leaf blight) and other foliar pathogens may have contributed to the increase in gray leaf spot.

Corresponding author: L. D. Dunkle; E-mail address: dunkle@btny.purdue.edu

Names are necessary to report factually on available data. However, the USDA neither guarantees nor warrants the standard of the product, and the use of the names implies no approval of the product to the exclusion of others that may also be suitable.

Publication no. P-1998-1014-01R

This article is in the public domain and not copyrightable. It may be freely reprinted with customary crediting of the source. The American Phytopathological Society, 1998.
Most commercial hybrids are moderately to highly susceptible to $C$. zeae-maydis, but a number of breeding programs have directed considerable effort toward discovering resistant or tolerant maize germ plasm. Genetic analyses have indicated that resistance is determined by quantitative trait loci (QTL) with additive gene action $(6,27,44)$ or by dominant gene(s) with major effects $(12,18)$. Resistance to gray leaf spot, expressed as a reduction in the rate of disease increase from secondary inoculum or as reduced size and number of lesions, has been discovered in a number of maize inbred lines $(9,11,15,19,45)$. The chlorotic lesion phenotype, a form of resistance controlled by a dominant allelic interaction in some inbreds, decreases the rate of disease progress and may provide effective control of gray leaf spot $(15,16)$.

In field trials, a significant genotype $\times$ environment (hybrid $\times$ location) interaction is frequently observed $(2,6,7,19,44)$. Such variation may be due to differential sensitivities of maize genotypes to environmental factors that impact disease severity, since the QTL effects associated with resistance to gray leaf spot are inconsistent over environments (6). But the possibility that the pathogen is genetically variable (7) or that the pathogen population is not geographically homogeneous cannot be dismissed. There is little evidence that the virulence of $C$. zeae-maydis is changing (44) or that races of the pathogen exist. However, Latterell and Rossi (21) described variation in certain structural, cultural, and metabolic characteristics among isolates of $C$. zeae-maydis and suggested that such variation also may be expressed in pathogenicity or aggressiveness. Bair and Ayers (2) observed variability in components of parasitic fitness (disease efficiency and virulence measured as lesion length) among 15 isolates of $C$. zeae-maydis from five eastern states. The mechanism generating variability is not known; neither a sexual stage nor parasexuality has been demonstrated in this pathogen. Although a teleomorphic stage in the genus Mycosphaerella was found associated with gray leaf spot lesions in overwintered field specimens of maize tissue (22), its relation to C. zeae-maydis has 
TABLE 1. Origins and designations of Cercospora isolates analyzed in this study ${ }^{\mathrm{a}}$

\begin{tabular}{|c|c|c|c|}
\hline Designation $^{\mathrm{b}}$ & Location & Designation $^{\mathrm{b}}$ & Location \\
\hline $\mathrm{CO}-1$ & Burlington, CO & IN-8 & Tippecanoe Co., IN \\
\hline $\mathrm{CO}-2$ & Lamar, CO & IN-9 & Tippecanoe Co., IN \\
\hline NE-1 & Clay Co., NE & IN-10 & Washington Co., IN \\
\hline NE-2 & Fillmore Co., NE & IN-11 & Warren Co., IN \\
\hline NE-3 & Central/N. Central, NE & IN-12 & Gibson Co., IN \\
\hline NE-4 & Central/N. Central, NE & IN-13 & Tippecanoe Co., IN \\
\hline NE-5 & Central/N. Central, NE & IN-14 & Starke Co., IN \\
\hline NE-6 & Clay Co., NE & $\mathrm{IN}-15$ & Posey Co., IN \\
\hline NE-7 & Fillmore Co., NE & IN-16 & IN \\
\hline NE-8 & Fillmore Co., NE & IN-17 & Tippecanoe Co., IN \\
\hline NE-9 & Nuckolls Co., NE & IN-18 & Tippecanoe Co., IN \\
\hline NE-10 & York Co., NE & IN-19 & Tippecanoe Co., IN \\
\hline NE-11* & Lancaster Co., NE & IN-20 & Tippecanoe Co., IN \\
\hline NE-12* & Hamilton Co., NE & IN-21 & Tippecanoe Co., IN \\
\hline NE-13* & Thayer Co., NE & IN-22 & Tippecanoe Co., IN \\
\hline KS-1 & Deerfield, KS & IN-23 & Tippecanoe Co., IN \\
\hline KS-2 & Kiowa Co., KS & IN-24 & Tippecanoe Co., IN \\
\hline KS-3* & Colby, KS & IN-25 & Tippecanoe Co., IN \\
\hline $\mathrm{KS}-4 *$ & Doniphan Co., KS & IN-26 & Tippecanoe Co., IN \\
\hline $\mathrm{KS}-5^{*}$ & Finney Co., KS & IN-27 & Sullivan Co., IN \\
\hline KS-6* & Grant Co., KS & IN-28 & Tippecanoe Co., IN \\
\hline $\mathrm{KS}-7 *$ & Hoxie, KS & KY-1 & Woodford Co., KY \\
\hline $\mathrm{KS}-8 *$ & Hoxie, KS & KY-2 & Whitley Co., KY \\
\hline KS-9* & Smith Co., KS & KY-3 & Woodford Co., KY \\
\hline KS-10* & Seward Co., KS & KY-4 & Whitley Co., KY \\
\hline OK-1* & Enid, OK & $\mathrm{KY}-5^{*}$ & Fayette Co., KY \\
\hline $\mathrm{OK}-2^{*}$ & Enid, OK & $\mathrm{OH}-1$ & Apple Creek, OH \\
\hline $\mathrm{OK}-3^{*}$ & Enid, OK & $\mathrm{OH}-2$ & Apple Creek, OH \\
\hline OK-4* & Enid, OK & $\mathrm{OH}-3$ & Millersport, $\mathrm{OH}$ \\
\hline IA-1 & Conrad, IA & $\mathrm{OH}-4$ & Howard, $\mathrm{OH}$ \\
\hline IA-2 & Grinell, IA & OH-5 & Apple Creek, OH \\
\hline IA-3 & Conrad, IA & OH-6 & Millersport, OH \\
\hline IA-4 & Conrad, IA & $\mathrm{OH}-7$ & Loudonville, $\mathrm{OH}$ \\
\hline IA-5 & Grinell, IA & $\mathrm{OH}-8$ & Wooster, OH \\
\hline IA-6 & Malvern, IA & OH-9 & Howard, $\mathrm{OH}$ \\
\hline IA-7 & Montgomery Co., IA & $\mathrm{OH}-10$ & Millersport, $\mathrm{OH}$ \\
\hline IA-8 & Montgomery Co., IA & OH-11 & Wooster, $\mathrm{OH}$ \\
\hline IA-9 & Story Co., IA & OH-12 & Wooster, OH \\
\hline IA-10* & Johnston, IA & OH-13* & Apple Creek, OH \\
\hline IA-11* & Marion, IA & OH-14* & Ross Co., OH \\
\hline MN-1 & MN & OH-15* & Warsaw, OH \\
\hline MO-1 & Boonville, MO & NY-1 & Chemung, NY \\
\hline MO-2 & East Central, MO & NY-2 & Chemung, NY \\
\hline MO-3 & Boonville, MO & PA-1 & Franklin Park, PA \\
\hline MO-4 & East Central, MO & PA-2 & Franklin Park, PA \\
\hline MO-5 & East Central, MO & PA-3 & Franklin Park, PA \\
\hline MO-6 & East Central, MO & PA-4* & Oley, PA \\
\hline MO-7 & East Central, MO & $\mathrm{TN}-1 *$ & Union City, TN \\
\hline IL-1 & Fox Ridge, IL & VA-1 & Montgomery Co., VA \\
\hline IL-2 & Marine, IL & VA-2 & Wythe Co., VA \\
\hline IL-3 & Fox Ridge, IL & VA-3 & Montgomery Co., VA \\
\hline IL-4* & Collum, IL & NC-1 & Marion, NC \\
\hline IL-5* & Havana, IL & NC-2 & Davidson, NC \\
\hline IL-6* & Macomb, IL & NC-3 & Salisbury, NC \\
\hline IL-7* & Sheldon, IL & $\mathrm{NC}-4$ & Laurel Springs, NC \\
\hline IL-8* & Urbana, IL & NC-5 & Marion, NC \\
\hline IN-1 & Knox Co., IN & NC-6* & Davidson, NC \\
\hline IN-2 & Marshall Co., IN & NC-7* & Randolph Co., NC \\
\hline IN-3 & Posey Co., IN & $\mathrm{CS}-1^{\mathrm{c}}$ & Corpus Christi, TX \\
\hline IN-4 & Tippecanoe Co., IN & CS-2 & Beeville, TX \\
\hline IN-5 & Tippecanoe Co., IN & CS-3 & $\mathrm{TX}$ \\
\hline IN-6 & Tippecanoe Co., IN & CS-4 & College Station, TX \\
\hline IN-7 & Tippecanoe Co., IN & & \\
\hline
\end{tabular}

${ }^{a}$ Leaf samples were collected and provided by J. Ayers, C. Berg, G. Bergstrom, M. Carson, L. Claflin, M. Dunkle, J. Grogan, P. Lipps, C. Martinson, G. Odvody, J. Perkins, E. Stromberg, P. Vincelli, D. White, D. Wilkinson, and D. Wysong.

${ }^{b}$ Designation corresponds to notation of isolates analyzed by amplified fragment length polymorphism (AFLP) and used in the cluster analysis presented in Figure 2. Isolates labeled with an asterisk $\left(^{*}\right)$ were not included in the AFLP analyses.

${ }^{\mathrm{c}}$ Isolates designated CS are C. sorghi. not been confirmed or documented definitively. Spermogonia bearing spermatia, considered the fertilization structures during sexual reproduction in some ascomycetous species, have been observed in cultures (22) and produced from stromatic cells formed in substomatal cavities within leaf lesions (23). However, others (5) have not observed these putative sexual reproductive structures, and their role, if any, in the life cycle is unknown.

The objectives of this study were to (i) detect and quantify genetic variability of $C$. zeae-maydis in the United States, and (ii) determine the geographic distribution of the variation. Various molecular methods have been used to detect and quantify genetic variation in fungi and other plant pathogens. Among them, amplified fragment length polymorphism (AFLP) (47) has been used effectively to detect genetic variation in pathogenic fungi (26), arbuscular mycorrhizal fungi (39), and populations of the potato cyst nematode (14) and to develop a genetic linkage map for a plant-pathogenic member of the class Oomycetes (46). We obtained isolates of the gray leaf spot pathogen from maize-producing areas of the United States and analyzed them for genetic variability by AFLP and by comparison of nucleotide sequences of the internal transcribed spacer (ITS) regions and 5.8S ribosomal DNA (rDNA). Our results indicated that two clearly distinct groups of $C$. zeae-maydis were isolated from disease lesions and suggest that two sibling species are independently associated with gray leaf spot of maize in the United States.

\section{MATERIALS AND METHODS}

Isolation and culture of fungal pathogens. Leaves exhibiting necrotic gray leaf spot lesions were collected from maize-production regions throughout the United States. Single, well-separated lesions were excised, surface-sterilized, and incubated on moist filter paper at $24^{\circ} \mathrm{C}$ for 24 to $48 \mathrm{~h}$ to allow sporulation. Cercospora conidia were removed and transferred to vials of sterile distilled water. The conidial suspension was spread over the surface of V8 juice agar and incubated at $24^{\circ} \mathrm{C}$ for 2 days, at which time single colonies were transferred to fresh medium. A minimum of two monoconidial isolates were obtained per lesion, and at least two lesions per location were sampled. The origins and designations of the isolates analyzed are listed in Table 1. Isolates of the sorghum pathogen $C$. sorghi were obtained similarly from sorghum leaves. The isolate of the soybean pathogen $C$. kikuchii was obtained from T. S. Abney (USDA-ARS, Purdue University).

The isolates were grown on potato dextrose agar (PDA) (Difco Laboratories, Detroit) to evaluate growth rates and cercosporin production (20) and on V8 juice agar to obtain conidia (5). Isolates were subcultured only once or twice prior to DNA analyses to minimize the potential of mutational changes (31). To obtain mycelium for DNA preparations, liquid-modified Fries' medium (36) in Erlenmeyer flasks was inoculated with conidia harvested from cultures grown on V8 juice agar. The inoculated flasks were incubated in a rotary shaker at $24^{\circ} \mathrm{C}$ for 10 to 14 days, at which time the mycelium was harvested by filtration through Miracloth (Calbiochem, La Jolla, CA) and frozen at $-80^{\circ} \mathrm{C}$.

Analysis of genomic variation. DNA was extracted from frozen mycelia by the hexadecyltrimethylammonium bromide (CTAB) method $(42,49)$ and quantified by spectrophotometry. Genomic variation was evaluated by AFLP analysis as described by Vos et al. (47). Genomic DNAs were digested with EcoRI and MseI and ligated with double-stranded adapters. The ligation products were preamplified with the EcoRI (E) and MseI (M) primers. Preamplified DNA was used as a template for selective amplification with EcoRI primer with one selective base, primer E+A, as the ${ }^{33} \mathrm{P}$-labeled primer, and either $\mathrm{Mse}$ I primer $\mathrm{M}+\mathrm{AT}$ or $\mathrm{M}+\mathrm{CA}$, both with two selective bases, as the unlabeled primer. Although a number of primer combinations was tested, the results reported herein were obtained with $\mathrm{E}+\mathrm{A} / \mathrm{M}+\mathrm{AT}$ or $\mathrm{E}+\mathrm{A} / \mathrm{M}+\mathrm{CA}$. AFLP-polymerase chain reaction $(\mathrm{PCR})$ products were separated by electrophoresis at $45 \mathrm{~W}$ for 2 to $3 \mathrm{~h}$ on a sequencing gel containing $5 \%$ polyacryla- 
mide and 7.5 $\mathrm{M}$ urea in $45 \mathrm{mM}$ Tris-borate and $1 \mathrm{mM}$ EDTA, $\mathrm{pH} 8$. The gel was dried and exposed to X-ray film overnight.

Comparative analysis of AFLP profiles. To assess the genetic similarity among isolates from maize and isolates of C. sorghi and C. kikuchii, each isolate was characterized for AFLP loci between 50 and 500 nucleotides in length. The loci were scored visually as present or absent, and the AFLP profiles were converted to binary data. Genetic similarities among isolates were evaluated from pairwise comparisons of the proportion of shared AFLP loci (Dice coefficient) as described by Levy et al. (24) and a phenetic cluster analysis of all pairwise data by the unweighted pair group method with arithmetic averaging. The cluster analysis was plotted in a phenogram. All computations were performed with SAS (version 6.09) programs (SAS Institute, Cary, NC).

Direct sequencing and analysis of the ITS regions of rDNA. Sequencing primers ITS1, ITS2, ITS3, and ITS4 (48) were used to obtain overlapping sequences from both strands of the ITS/5.8S rDNA fragment. Nucleotide sequences of four isolates of each species (except $C$. kikuchii) were obtained with the Gibco BRL dsDNA Cycle Sequencing System (Life Technologies, Gaithersburg, MD). Each sequencing reaction contained $20 \mathrm{ng}$ of DNA, 0.2 pmol of ${ }^{33} \mathrm{P}$-labeled primer, $0.3 \mathrm{U}$ of Taq polymerase, Taq sequencing buffer, and termination mix A, C, G, or T. Reactions were run in a Perkin-Elmer DNA thermal cycler model 480 (PerkinElmer, Foster City, CA) for 20 cycles of $95^{\circ} \mathrm{C}$ for $30 \mathrm{~s}, 55^{\circ} \mathrm{C}$ for $30 \mathrm{~s}$, and $70^{\circ} \mathrm{C}$ for $60 \mathrm{~s}$, following an initial 3-min incubation at $95^{\circ} \mathrm{C}$. Reaction products were separated on a sequencing gel, and sequences were determined visually.

For restriction fragment length polymorphism (RFLP) analysis, genomic DNA was amplified by PCR with primers ITS4 and ITS5 (48) as described by Shi et al. (40). The amplified ITS fragment was purified by extraction with chloroform, precipitated with ethanol, and digested with restriction endonucleases (New England Biolabs, Inc., Beverly, MA) as indicated. Digestion products were separated by electrophoresis on $3 \%$ agarose gels.

\section{RESULTS}

Cultural characteristics. All isolates were obtained from single, typical necrotic gray leaf spot lesions delimited by major leaf veins. Fascicles of conidiophores, usually dense and compact, but sometimes loosely organized, arose from stromatic tissue in the substomatal cavity of the leaf. Conidiophores were straight, unbranched, olivaceous, and had three to five septa, a uniform diameter of $5 \mu \mathrm{m}$, and an average length of $129 \mu \mathrm{m}$. Most conidiophores had one or two geniculations after incubation of the lesions in moist conditions for a few days to allow for multiple cycles of conidiation in accord with previous observations $(4,23)$. Conidia were hyaline and obclavate with three to seven septa. Conidia of most isolates measured 6 to $9 \mu \mathrm{m} \times 37$ to $76 \mu \mathrm{m}$ (average of $7.2 \times 67.4 \mu \mathrm{m}$ ); conidia of some isolates measured 8 to $13 \mu \mathrm{m} \times 44$ to $80 \mu \mathrm{m}$ (average of $10.5 \times 70 \mu \mathrm{m})$. Those characteristics are consistent with taxonomic descriptions for $C$. zeae-maydis $(8,43)$.

Vegetative growth on PDA consisted of a dark-gray mycelium that produced a reddish purple compound after approximately 4 to 7 days of growth in the light on PDA. This pigment was identified as the phytotoxin cercosporin by the characteristic absorption spectrum after extraction from the medium into $\mathrm{KOH}(3,20)$. Some isolates grew more slowly and produced barely visible amounts of cercosporin after 14 to 21 days. Cultures of both the fast- and slow-growing isolates frequently produced sectors of white mycelium, which were not associated with cercosporin, and in general, could not be induced to produce conidia upon subculturing onto V8 juice agar. No attempt was made to optimize conditions for cercosporin production by manipulating the temperature or nutrient medium.

Many of the fast-growing isolates from maize produced spermogonia-like structures that released large quantities of hyaline, elliptical, single cells that appeared similar to spermatia. These putative spermatia could not be induced to germinate on any medium tested or over a range of temperatures in light or dark.

AFLP analyses. Isolates were examined for genetic variability by AFLP analysis. To determine whether DNA of a single isolate from a lesion reliably and accurately represented the genetic composition of the causal organism, we analyzed 12 monoconidial isolates from one lesion on a leaf collected in Pennsylvania and 20 isolates from one lesion on a leaf collected in Colorado. In each sample, the AFLP profiles were monomorphic (data not shown), suggesting that each lesion was caused by a single infection or by multiple infections by conidia with identical haplotypes.

A total of 91 monoconidial isolates from gray leaf spot lesions were analyzed by AFLP. Isolates from the western and midwestern corn belt exhibited similar AFLP profiles with a detectable but limited number of polymorphic fragments among those isolates (Fig. 1). The profiles of some isolates from the eastern part of the corn belt were very similar or identical to those of isolates from the western and midwestern areas, whereas profiles of other isolates were very different. Two distinct groups of AFLP profiles were obvious with any of several primers, although the number of amplified fragments and the extent of polymorphism differed with the primers (data not shown). In some instances, isolates representing each AFLP group were obtained from the same fields, e.g., in Apple Creek, $\mathrm{OH}$; Wooster, $\mathrm{OH}$; and Chemung, $\mathrm{NY}$, indicating that the two groups were sympatric in the eastern corn belt.

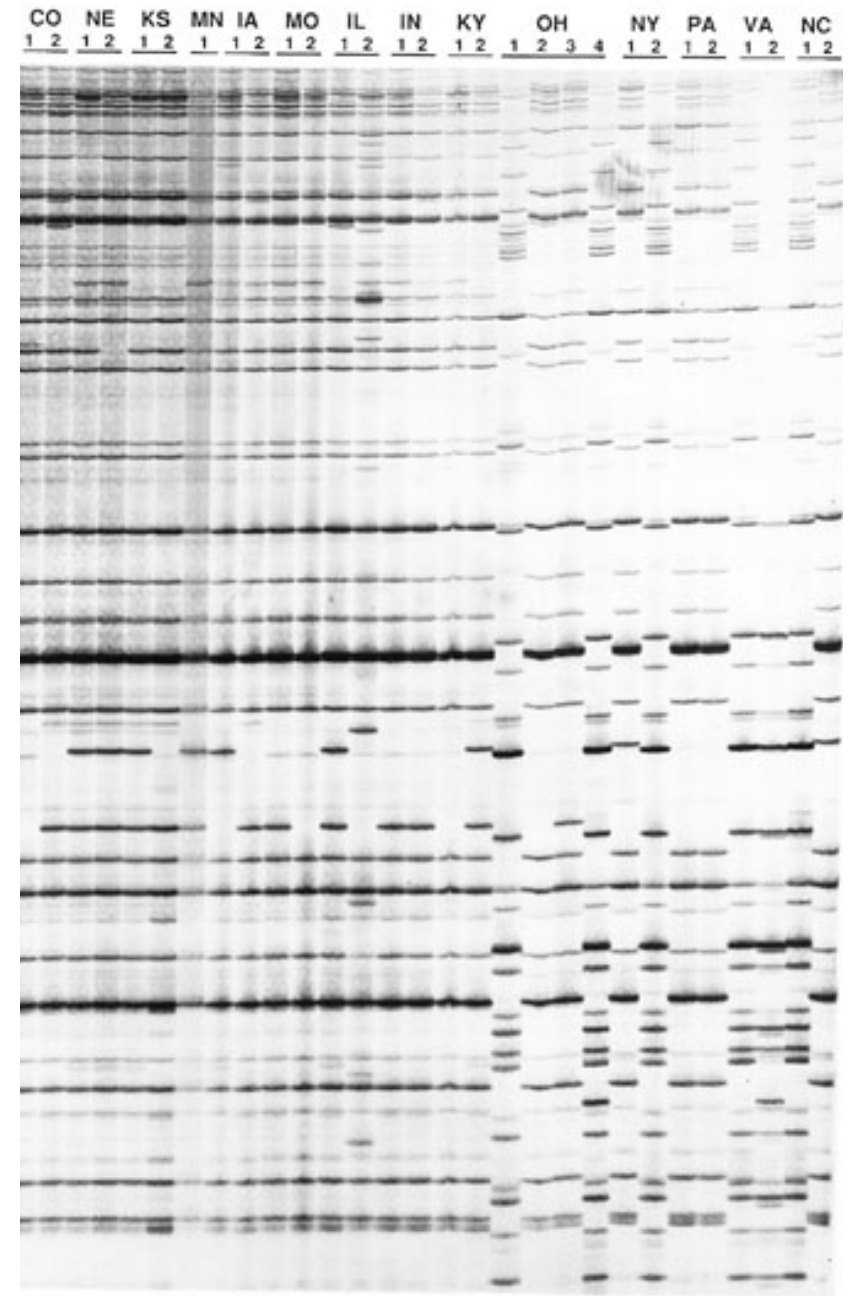

Fig. 1. Amplified fragment length polymorphism profiles of selected monoconidial isolates from gray leaf spot lesions collected in the states abbreviated at the top of each lane. The fragments shown range from approximately 50 to 750 nucleotides long and were generated with primer pair E+A/M+CA (described in Materials and Methods). 
Cluster analysis (Fig. 2) separated the 91 maize isolates into two very distinct AFLP groups with an average genetic distance of nearly $80 \%$ (Table 2). For convenience, these two groups are referred to hereafter as C. zeae-maydis group I and C. zeae-maydis group II. Each group was separated from $C$. sorghi by an average genetic distance of at least $67 \%$. Within each group, the vast majority of the AFLP loci evaluated were consensus bands, i.e., present in $90 \%$ or more of the isolates (Table 2). Although each group contained a large proportion of unique haplotypes, each haplotype differed by only a few polymorphic loci. Consequently, the population of isolates within each group was relatively uniform with average genetic similarities among isolates of $93 \%$ (range of 81 to $100 \%$ ) and $94 \%$ (range of 89 to $99 \%$ ), respectively (Table 2).

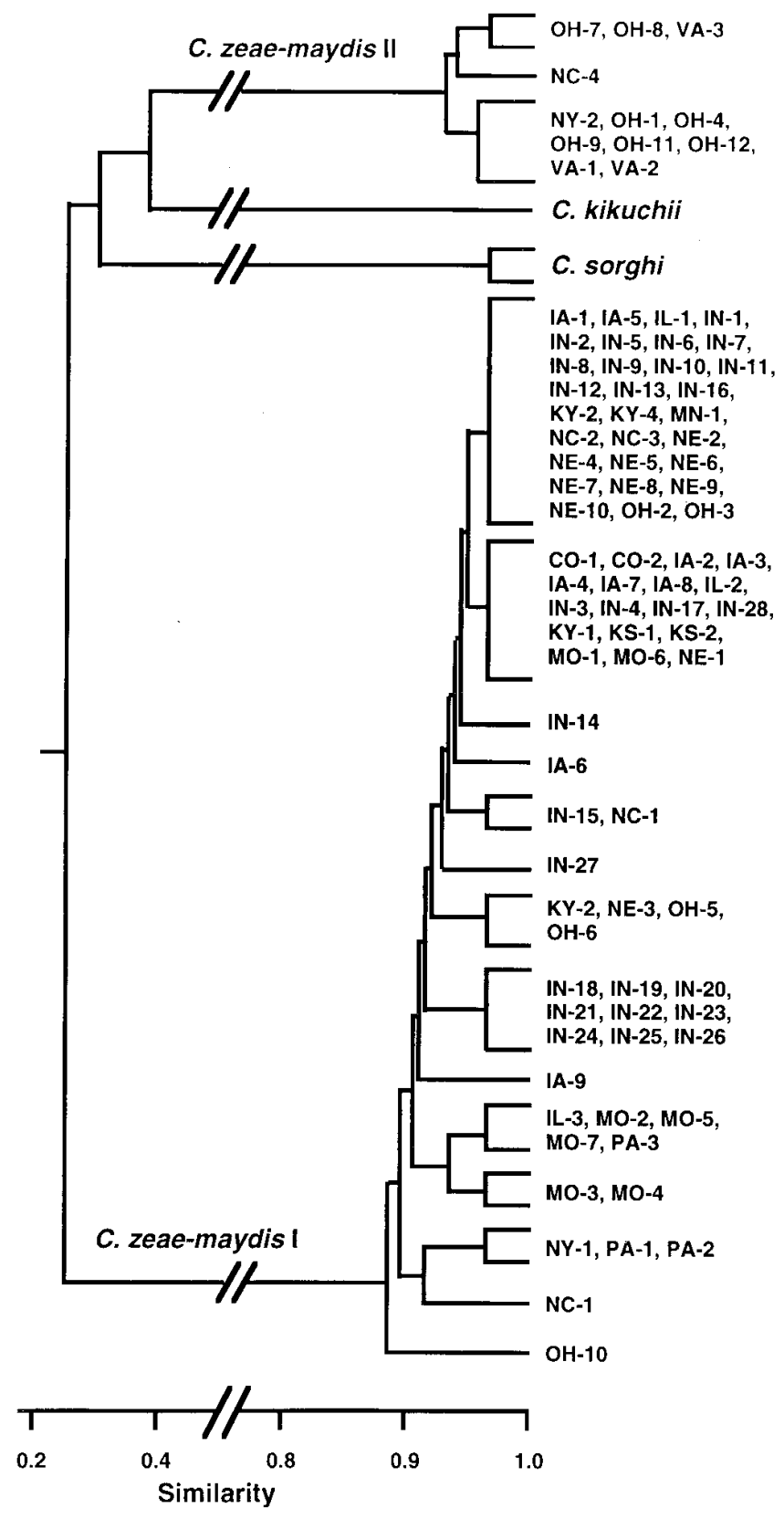

Fig. 2. Unweighted pair group method with arithmetic averaging (UPGMA) phenogram of amplified fragment length polymorphism (AFLP) profile variation among isolates of Cercospora species. Origins of isolates are listed in Table 1. Branches that bracket multiple isolates include all profiles with $95 \%$ or greater similarity. Variation within each species or group of $C$. zeae-maydis is limited (average similarity greater than $92 \%$ ) and each is discretely different from all others (average similarity less than 40\%). AFLP loci between 50 and 500 nucleotides long generated with two primer pairs $(\mathrm{E}+\mathrm{A} / \mathrm{M}+\mathrm{AT}$ and $\mathrm{E}+\mathrm{A} / \mathrm{M}+\mathrm{CA}$ ) were scored.
AFLP analysis of 20 isolates from different plants in the same field in Indiana indicated that genetic variation in the pathogen within a field essentially reflected its variation within the state (data not shown). Furthermore, the distribution of haplotypes within each group was geographically homogenized. Thus, the maize isolates compose two morphologically identical (or taxonomically indistinct) and partially sympatric groups that do not appear to interact genetically.

Analysis of ITS and 5.8S rDNA. The nucleotide sequences of the ITS regions and 5.8S rDNA are shown in Figure 3 for $C$. zeaemaydis group I, C. zeae-maydis group II, and C. sorghi. No variation in the sequences was detected among the four isolates of each group or species that were analyzed. The sequence of $C$. zeaemaydis group I differs from that of the group II isolates by a total of seven nucleotides, six of which are in the ITS regions (Fig. 3). The sequences of $C$. zeae-maydis group II and $C$. sorghi differ by five nucleotides, all of which are in the ITS regions. A search of the sequences for restriction endonuclease sites revealed potential enzymes that could be used to distinguish each of the three by their RFLPs. For example, the difference $(\mathrm{C}$ versus $\mathrm{T})$ at position 107 results in the presence of an MmeI site (TCCGAC) in C. zeaemaydis group I that is absent from the other two and the absence of a TaqI site (TCGA) in C. zeae-maydis group I that is present in the other two. Similarly, the difference (T versus C) at position 413 results in a DdeI site (CTNAG) in $C$. zeae-maydis group I and $C$. sorghi that is absent from $C$. zeae-maydis group II. The difference at position 419 (T versus C) results in CfoI and HhaI sites (GCGC) only in $C$. zeae-maydis group II. The differences at positions 385 and 386 (TA versus CG versus CA) result in an MseI site only in C. zeae-maydis group I, a TaqI site only in group II, and neither site in C. sorghi. Thus, C. zeae-maydis group I contained four TaqI sites, group II contained six, and C. sorghi contained five (Fig. 3). The pattern of restriction fragments generated by digestion of ITS and 5.8S rDNA with TaqI identified and distinguished each group or species from the other two (Fig. 4). Results of this approach confirmed the separation of groups that was indicated by AFLP analyses; without exception, the isolates with AFLP profiles that were typical of $C$. zeae-maydis group I had identical RFLP patterns, and the isolates with AFLP profiles typical of $C$. zeaemaydis group II had identical RFLP patterns.

Distribution of gray leaf spot pathogens. Restriction digestion of ITS and 5.8S rDNA with TaqI was used to identify 121 maize isolates (Table 1) and to determine the geographic distribution of each group within the United States. Figure 5 shows that $C$. zeae-maydis group I is most prevalent and is generally distributed throughout the country including the area where the fungus was initially discovered. Isolates of group II are localized only in the eastern third of the country.

The locations of isolates analyzed (Fig. 5) do not define the distribution range of gray leaf spot; the disease is known to occur in other eastern (e.g., Maryland), northern (e.g., Wisconsin), and southern (e.g., Texas, South Carolina, and Georgia) states that

TABLE 2. Amplified fragment length polymorphism diversity in Cercospora zeae-maydis and related species determined by UPGMA ${ }^{\text {a cluster analysis }}$

\begin{tabular}{|c|c|c|c|c|}
\hline & \multicolumn{2}{|c|}{ C. zeae-maydis } & \multirow{2}{*}{$\begin{array}{c}C . \\
\text { sorghi }\end{array}$} & \multirow{2}{*}{$\begin{array}{c}\text { C. } \\
\text { kikuchii }\end{array}$} \\
\hline & Group I & Group II & & \\
\hline No. of isolates analyzed & 79 & 12 & 4 & 1 \\
\hline No. of loci scored & 58 & 53 & 40 & 40 \\
\hline No. of haplotypes & 67 & 12 & 4 & 1 \\
\hline Average no. of loci/haplotype & 41.0 & 43.9 & 37.5 & 40 \\
\hline No. of $90 \%$ consensus loci & 34 & 40 & 35 & 40 \\
\hline Average similarity $(\%)$ & 92.8 & 94.0 & 95.9 & \\
\hline Range similarity (\%) & $81-100$ & 89-99 & $95-97$ & \\
\hline \multicolumn{5}{|l|}{ Average genetic similarity (\%) } \\
\hline C. zeae-maydis group I & & 20.1 & 29.7 & 27.6 \\
\hline C. zeae-maydis group II & & & 32.7 & 36.5 \\
\hline C. sorghi & & & & 28.9 \\
\hline
\end{tabular}

${ }^{\text {a }}$ Unweighted pair group method with arithmetic averaging (Fig. 2). 
were not sampled. Samples from eastern Colorado were collected from fields with center pivot irrigation systems and with debris of the previous maize crop(s) on the soil surface. The sample collected in northcentral Oklahoma was from a predominantly wheatgrowing area in which maize is produced only rarely. Those collections extend the distribution records of gray leaf spot, indicating that $C$. zeae-maydis continues to advance into areas of maize production that were previously devoid of the disease.

\section{DISCUSSION}

The species concept and taxonomy in Cercospora are based upon morphological criteria, primarily the dimensions and characteristics of the conidia (length, width, base, and tip) and conidiophores (length, diameter, geniculation, and fasciculation) (8). In his monograph on the genus, Chupp (8) discussed the reliability of the various characteristics used to distinguish and identify the species. Among the characteristics of conidia, spore width is considered to be the most reliable feature. Indeed, this characteristic is a major criterion used to distinguish $C$. zeae-maydis and $C$. sorghi, both of which are isolated from maize leaves. In general, other conidial features are less reliable, because they are either influenced to a large extent by environmental conditions (e.g., length) or represented by too few distinctive forms (e.g., features of the conidial tip) to be consistently dependable (8). Characteristics of the conidiophores are generally less reliable than characteristics of conidia. The length of the conidiophore and the extent of geniculation are influenced by temperature and moisture, and the diameter and the number of conidiophores per fascicle are too variable to be taxonomically decisive. In fact, authoritative descriptions of $C$. zeae-maydis $(8,23,43)$ differ in some characteristics of the conidia and conidiophores.

Although morphological characteristics limited our attempts to distinguish two species of Cercospora, molecular criteria clearly indicated that two distinct groups of isolates are associated with gray leaf spot lesions. Comparative AFLP analysis indicated that C. zeae-maydis group I and group II are as different from each

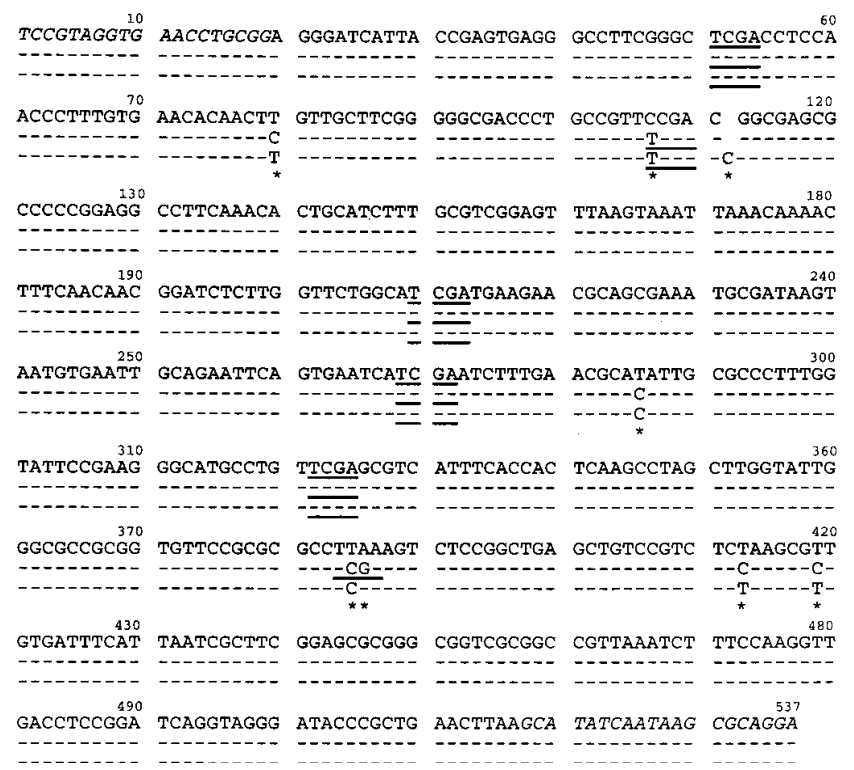

Fig. 3. Nucleotide sequences of the $5.8 \mathrm{~S}$ ribosomal DNA (rDNA) and internal transcribed spacer (ITS) regions of Cercospora zeae-maydis group I (top line), C. zeae-maydis group II (middle line), and C. sorghi (bottom line). The region from 177 to 333 represents the 5.8S rDNA. Italicized sequences at the termini indicate conserved primers ITS1 and ITS4. Underlined sequences indicate $T a q \mathrm{I}$ restriction sites. Nucleotides that are identical in all three are indicated with a dash (-); nucleotides that differ in one sequence from the other two are recorded and indicated with an asterisk $(*)$ below. Four isolates of each group or species were analyzed, and the sequences within each were identical. other as they are from the other congeneric species included in the analyses, C. sorghi and C. kikuchii (Table 2). The number of nucleotide differences in ITS sequences between the two groups of maize isolates (six) also is consistent with the genetic distances between them and other Cercospora congeners as well as those that distinguish species of Penicillium (35). Furthermore, each group was characterized by distinct fingerprints by PCR with primers to enterobacterial repetitive intergenic consensus (ERIC) sequences and repetitive intergenic consensus (REP) sequences (L. D. Dunkle, unpublished data) and by random amplified polymorphic DNA analyses (7; L. D. Dunkle, unpublished data). Thus, we conclude that the two groups of Cercospora isolates from maize represent independent, though partially sympatric, gene pools that have become differentiated to a level observed between recognized congeneric fungal species. Following the definition coined by Mayr (28), we conclude that these two groups are best considered as sibling species of each other. We note that sibling species, as strictly defined, need not be each others' closest relative in terms

\section{$\begin{array}{llll}\text { C. } z-m \text { I } & \text { C. } z-m \| \text { II } & \text { C. sorghi }\end{array}$}

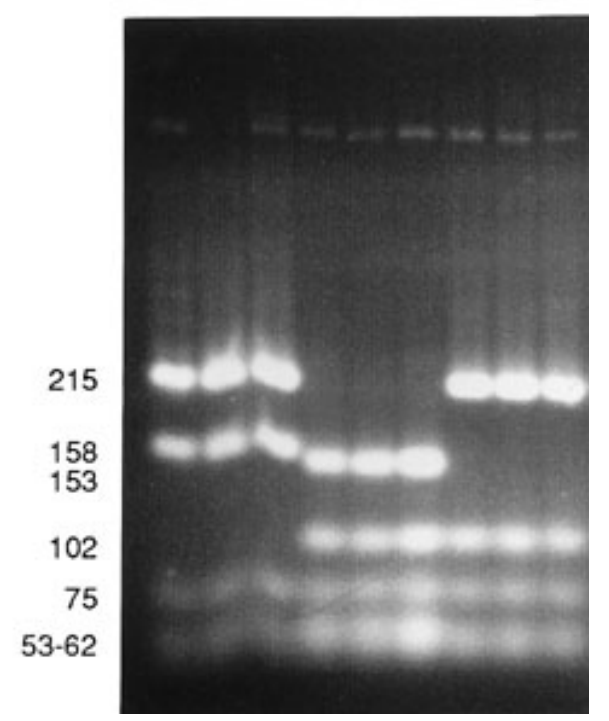

Fig. 4. Differentiation of three species of Cercospora by digestion of the 5.8S ribosomal DNA and internal transcribed spacer (ITS) sequences with TaqI. Fragments were amplified with primers ITS5 and ITS4 from genomic DNA of three isolates each of C. zeae-maydis group I (C. z-m I), C. zeaemaydis group II (C. z-m II), and C. sorghi. The digestion products were separated by electrophoresis on 3\% agarose gels. Values in the left margin are sizes (in base pairs) of the digestion products.

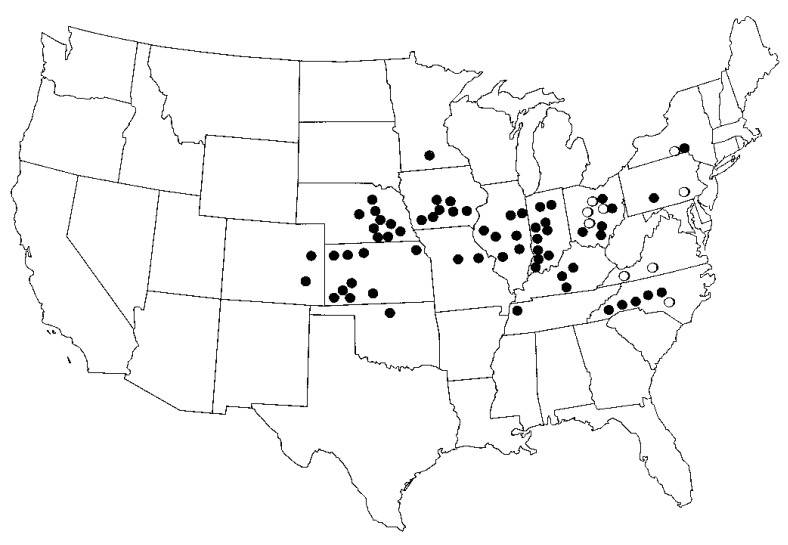

Fig. 5. Distribution of Cercospora zeae-maydis group I (filled circles) and $C$. zeae-maydis group II (open circles) as determined by restriction patterns resulting from TaqI digestion of the 5.8S ribosomal DNA and internal transcribed spacer regions of the isolates listed in Table 1. 
of genetic distance (29). However, until additional criteria are available to delimit Cercospora species, these groups must be considered to be taxonomically conspecific.

Similar conclusions were derived from studies of a collection of isolates of Aspergillus flavus (17). Analyses of DNA sequences and restriction site polymorphisms in protein-coding genes revealed two sympatric, reproductively isolated groups, that Geiser et al. (17) concluded should be considered different biological species despite the fact that they are morphologically identical. On the other hand, evidence from molecular analyses did not support the species separation of A. flavus and A. oryzae, which are morphologically different. Although secondary metabolism is not a generally useful taxonomic characteristic, the separation of those species is based upon the production of aflatoxin, a capability of A. flavus that is lacking in A. oryzae. Many species of Cercospora produce cercosporin, a secondary metabolite with phytotoxic activity. In general, members of $C$. zeae-maydis group I produce considerably more cercosporin in culture than do isolates in group II, but there is sufficient variation among the isolates to preclude cercosporin production from being a distinguishing feature. Further, among species of Cercospora, nutritional and physical conditions differentially affect cercosporin production such that conditions that are optimal for one species or an isolate of that species may not be optimal for another $(20,41)$.

The host plant is frequently used a priori to determine the species of a fungal pathogen in the absence of distinctive and taxonomically unambiguous morphological characters. This dependence relies upon a reasonably narrow host range. The only plant species recognized as a host for $C$. zeae-maydis is maize, and the only species of Cercospora recognized as maize pathogens are $C$. zeaemaydis and $C$. sorghi (13). However, the evidence for host specialization in species of Cercospora is equivocal. For example, the conspecificity of $C$. sorghi and $C$. sorghi var. maydis was questioned by Chupp (8), citing failure of the former to infect maize. He cautioned that the two may be different species, even though C. sorghi var. maydis appears very similar to the type specimen of C. sorghi. Likewise, Odvody (32) questioned the identification of C. sorghi as a pathogen of maize based on inoculation experiments and suggested that another species of Cercospora is involved.

The mechanisms by which genetic diversity may arise in $C$. zeae-maydis have not been established. Parasexuality has never been demonstrated in this species, and the involvement of a sexual stage in the life cycle is debatable. We were unsuccessful in repeated attempts to induce a sexual stage in our isolates by incubating them separately or in pairs under various physical conditions on maize leaves or on a number of nutrient media. Likewise, we could not obtain evidence for a mating type gene in our isolates of Cercospora by PCR with primers to conserved sequences within the MAT-2 idiomorph in numerous members of the class Loculoascomycete including M. zeae-maydis (1).

Variation in gray leaf spot severity among locations is most frequently attributed to environmental conditions and tillage practices. The disease is significantly influenced by temperature and the duration of high humidity as well as by inoculum potential and hybrid genotype. Although we have no data that bear directly on the impact of genetic variation in the fungal pathogen or on genotype $\times$ environment interactions, the results of the current study suggest that those effects may be minimal. The genetic variation within the population of each $C$. zeae-maydis group is very low, and the diversity that does exist is homogenized such that haplotype distribution follows no geographic pattern. Results of our analyses differ from those of McDonald and Martinez (30), who detected genetic diversity among isolates of M. graminicola (Septoria tritici) from the same lesion on wheat leaves and concluded that the pathogen population was highly diverse. We found that isolates from the same gray leaf spot lesion were indistinguishable by AFLP and that the extent of variation within a field was similar to that within a state.
Gray leaf spot monitoring plots maintained across the United States in 1996 and 1997 indicated that the relative disease severity rankings of hybrids with a range of disease phenotypes do not change significantly from location to location (25). Consequently, it appears that neither of the sibling Cercospora species has selected maize genotypes that are more susceptible to one than to the other. It is possible that some hybrids are more sensitive to certain components or combinations of environmental factors and, thus, are predisposed to more severe infection and gray leaf spot development under those conditions. Although it is unlikely that breeding for and selecting resistance to gray leaf spot will be confounded by local or regional variation in the pathogen, a vigilant approach is warranted, because two pathogenic species exist with unknown abilities to evolve new pathotypes.

\section{ACKNOWLEDGMENTS}

Research reported is a cooperative investigation of the U.S. Department of Agriculture-Agricultural Research Service and the Purdue University Agricultural Experiment Station. Published as paper no. 15718, Purdue University Agricultural Experiment Station. We thank M. McClenning for excellent technical assistance and M. Carson, S. Goodwin, and P. Lipps for valuable discussions.

\section{LITERATURE CITED}

1. Arie, T., Christiansen, S. K., Yoder, O. C., and Turgeon, B. G. 1997. Efficient cloning of Ascomycete mating type genes by PCR amplification of the conserved MAT HMG box. Fungal Genet. Biol. 21:118-130.

2. Bair, W., and Ayers, J. E. 1986. Variability in isolates of Cercospora zeae-maydis. Phytopathology 76:129-132.

3. Balis, C., and Payne, M. G. 1971. Triglycerides and cercosporin from Cercospora beticola: Fungal growth and cercosporin production. Phytopathology 61:1477-1484.

4. Beckman, P. M., and Payne, G. A. 1982. External growth, penetration, and development of Cercospora zeae-maydis in corn leaves. Phytopathology 72:810-815.

5. Beckman, P. M., and Payne, G. A. 1983. Cultural techniques and conditions influencing growth and sporulation of Cercospora zeae-maydis and lesion development in corn. Phytopathology 73:286-289.

6. Bubeck, D. M., Goodman, M. M., Beavis, W. D., and Grant, D. 1993. Quantitative trait loci controlling resistance to gray leaf spot in maize. Crop Sci. 33:838-847.

7. Carson, M. L., Goodman, M. M., Williamson, S. M., Haralambous, V., and Nyanapah, J. O. 1997. Pathogen variability as a potential cause of genotype $\times$ environment interaction in maize gray leaf spot trials. (Abstr.) Phytopathology 87:S15.

8. Chupp, C. 1953. A Monograph of the Fungus Genus Cercospora. Ronald Press Co., Ithaca, NY.

9. Coates, S. T., and White, D. G. 1994. Sources of resistance to gray leaf spot of corn. Plant Dis. 78:1153-1155.

10. de Nazareno, N. R. X., Lipps, P. E., and Madden, L. V. 1993. Effect of levels of corn residue on the epidemiology of gray leaf spot of corn in Ohio. Plant Dis. 77:67-70.

11. Donahue, P. J., Stromberg, E. L., and Myers, S. L. 1991. Inheritance of reaction to gray leaf spot in a diallel cross of 14 maize inbreds. Crop Sci. 31:926-931.

12. Elwinger, G. F., Johnson, M. W., Hill, R. R., and Ayers, J. E. 1990. Inheritance of resistance to gray leaf spot of corn. Crop Sci. 30:350-358.

13. Farr, D. F., Bills, G. F., Chamuris, G. P., and Rossman, A. Y. 1989. Fungi on Plants and Plant Products in the United States. The American Phytopathological Society, St. Paul, MN.

14. Folkertsma, R. T., Rouppe van der Voort, J. N. A. M., de Groot, K. E., van Zandvoort, P. M., Schots, A., Gommers, F. J., Helder, J., and Bakker, J. 1996. Gene pool similarities of potato cyst nematode populations assessed by AFLP analysis. Mol. Plant-Microbe Interact. 9:47-54.

15. Freppon, J. T., Lipps, P. E., and Pratt, R. C. 1994. Characterization of the chlorotic lesion response by maize to Cercospora zeae-maydis. Plant Dis. 78:945-949.

16. Freppon, J. T., Pratt, R. C., and Lipps, P. E. 1996. Chlorotic lesion response of maize to Cercospora zeae-maydis and its effect on gray leaf spot disease. Phytopathology 86:733-738.

17. Geiser, D. M., Pitt, J. I., and Taylor, J. W. 1998. Cryptic speciation and recombination in the aflatoxin-producing fungus Aspergillus flavus. Proc. Natl. Acad. Sci. U.S.A. 95:388-393. 
18. Gevers, H. O., Lake, J. K., and Hohls, T. 1994. Diallel cross analysis of resistance to gray leaf spot in maize. Plant Dis. 78:379-383.

19. Huff, C. A., Ayers, J. E., and Hill, Jr., R. R. 1988. Inheritance of resistance in corn (Zea mays) to gray leaf spot. Phytopathology 78:790-794.

20. Jenns, A. E., Daub, M. E., and Upchurch, R. G. 1989. Regulation of cercosporin accumulation in culture by medium and temperature manipulation. Phytopathology 79:213-219.

21. Latterell, F. M., and Rossi, A. E. 1974. Structural, cultural, and metabolic variability in Cercospora zeae-maydis. (Abstr.) Proc. Am. Phytopathol. Soc. 1:26-27.

22. Latterell, F. M., and Rossi, A. E. 1977. Further evidence for the genetic relationship between Cercospora zeae-maydis and a species of $M y$ cosphaerella. (Abstr.) Page 374 in: Proc. Int. Mycol. Congr., 2nd.

23. Latterell, F. M., and Rossi, A. E. 1983. Gray leaf spot of corn: A disease on the move. Plant Dis. 67:842-847.

24. Levy, M., Correa-Victoria, F. J., Zeigler, R. S., Xu, S., and Hamer, J. E. 1993. Genetic diversity of the rice blast fungus in a disease nursery in Colombia. Phytopathology 83:1427-1433.

25. Lipps, P. E., White, D. G., Ayers, J. E., and Dunkle, L. D. 1998. Gray leaf spot of corn: Update. Technical Report of the North Central Region (NCR-25) Committee on Corn and Sorghum Diseases.

26. Majer, D., Mithen, R., Lewis, B. G., Vos, P., and Oliver, R. P. 1997. The use of AFLP fingerprinting for the detection of genetic variation in fungi. Mycol. Res. 100:1107-1111.

27. Maroof, M. A. S., Yue, Y. G., Xiang, Z. X., Stromberg, E. L., and Rufener, G. K. 1996. Identification of quantitative trait loci controlling resistance to gray leaf spot in maize. Theor. Appl. Genet. 93:539-546.

28. Mayr, E. 1942. Systematics and the Origin of Species. Columbia University Press, New York.

29. Mayr, E. 1970. Populations, Species, and Evolution. An Abridgment of Animal Species and Evolution. Belknap Press of Harvard University Press, Cambridge, MA.

30. McDonald, B. A., and Martinez, J. P. 1990. DNA restriction fragment length polymorphisms among Mycosphaerella graminicola (anamorph Septoria tritici) isolates collected from a single wheat field. Phytopathology 80:1368-1373.

31. Milgroom, M. G., Lipari, S. E., and Powell, W. A. 1992. DNA fingerprinting and analysis of population structure in the chestnut blight fungus, Cryphonectria parasitica. Genetics 131:297-306.

32. Odvody, G. N. 1986. Gray leaf spot. Pages 11-12 in: Compendium of Sorghum Diseases. R. A. Frederiksen, ed. The American Phytopathological Society, St. Paul, MN.

33. Payne, G. A., Duncan, H. E., and Adkins, C. R. 1987. Influence of tillage on development of gray leaf spot and number of airborne conidia of Cercospora zeae-maydis. Plant Dis. 71:329-332.

34. Payne, G. A., and Waldron, J. K. 1983. Overwintering and spore release of Cercospora zeae-maydis in corn debris in North Carolina. Plant Dis. 67:87-89.

35. Peterson, S. W. Phylogenetic analysis of Penicillium species based on ITS and 1su-rDNA nucleotide sequences. In: Proc. Int. Workshop Penicillium Aspergillus, 3rd. Kluwer Academic Publishers, Dordrecht, the Netherlands. In press.

36. Pringle, R. B., and Scheffer, R. P. 1963. Purification of the selective toxin of Periconia circinata. Phytopathology 53:785-787.

37. Roane, C. W. 1950. Observations on corn diseases in Virginia from 1947 to 1950 . Plant Dis. Rep. 34:394-396.

38. Roane, C. W., Harrison, R. L., and Genter, C. F. 1974. Observations on gray leaf spot of maize in Virginia. Plant Dis. Rep. 58:456-459.

39. Rosendahl, S., and Taylor, J. W. 1997. Development of multiple genetic markers for studies of genetic variation in arbuscular mycorrhizal fungi using AFLP. Mol. Ecol. 6:821-829.

40. Shi, Y. L., Loomis, P., Christian, D., Carris, L. M., and Leung, H. 1996. Analysis of the genetic relationships among the wheat bunt fungi using RAPD and ribosomal DNA markers. Phytopathology 86:311-318.

41. Steinkamp, M. P., Martin, S. S., Hoefert, L. L., and Ruppel, E. G. 1981. Ultrastructure of lesions produced in leaves of Beta vulgaris by cercosporin, a toxin from Cercospora beticola. Phytopathology 71:12721281.

42. Taylor, J. W., and Natvig, D. 1986. Isolation of fungal DNA. Pages 252258 in: Zoosporic Fungi in Teaching and Research. M. S. Fuller and S. A. Jaworsky, eds. Southeastern Publishing Company, Athens, GA.

43. Tehon, L. R., and Daniels, E. 1925. Notes on the parasitic fungi of Illinois. Mycologia 17:240-249.

44. Thompson, D. L., Bergquist, R. R., Payne, G. A., Bowman, D. T., and Goodman, M. M. 1987. Inheritance of resistance to gray leaf spot in maize. Crop Sci. 27:243-246.

45. Ulrich, J. F., Hawk, J. A., and Carroll, R. B. 1990. Diallel analysis of maize inbreds for resistance to gray leaf spot. Crop Sci. 30:1198-1200.

46. VanderLee, T., DeWitte, I., Drenth, A., Alfonso, C., and Govers, F. 1997. AFLP linkage map of the oomycete Phytophthora infestans. Fungal Genet. Biol. 21:278-291.

47. Vos, P., Hogers, R., Bleeker, M., Rejians, M., van de Lee, T., Hornes, M., Frijters, A., Pot, J., Peleman, J., Kuiper, M., and Zabeau, M. 1995. AFLP: A new technique for DNA fingerprinting. Nucleic Acids Res. 23:4407-4414.

48. White, T. J., Bruns, T., Lee, S., and Taylor, J. 1990. Amplification and direct sequencing of fungal ribosomal RNA genes for phylogenetics. Pages 315-322 in: PCR Protocols, A Guide to Methods and Applications. M. A. Innis, D. H. Gelfand, J. J. Sninsky, and T. J. White, eds. Academic Press, Inc., San Diego, CA.

49. Zolan, M. E., and Pukkila, P. J. 1986. Inheritance of DNA methylation in Coprinus cinereus. Mol. Cell. Biol. 6:195-200. 